\title{
CONSIDERATIONS CONCERNING POSSIBLE EXPLANATIONS OF THE EUROPEAN MULTICULTURAL SOCIETY FAILURE
}

\author{
Anca DINICU, Daniel-Sorin CONSTANTIN \\ „Nicolae Bălcescu” Land Forces Academy, Sibiu, Romania \\ anca_dinicu@yahoo.com, cdanielsorin@gmail.com
}

\begin{abstract}
The almost global democratization removed, among other things, the constraints on cooperation between the countries from all over the world. The collapse of ideological barriers has facilitated not only redesigning the states 'foreign policies on other foundations, but also a nongovernmental expansion through the many possibilities offered by the free movement of persons, material and spiritual goods, capital and services. All these, enhanced by the boom of social communication networks, have influenced national companies, giving them a touch of transnationality translated by heterogeneity in relation to which national governments seem unable to resist. The permeability of borders, one of the features of globalization, also applies in this case of influence and cultural communion, of movement of people and ideas. This paper aims to address the issue of multiculturalism generated by the migration phenomenon not as a factor of social cohesion, but as one able to induce disorder and adversity against those who are different. The analytical approach is based on the empirical study of the current European context, which is under deep pressure as a result of the immigration „Tsunami” generated largely by the complex situation in the Middle East and North Africa. Therefore, the two possible initialization research questions might be:

- are we confronting a single and big problem hanging over the entire geopolitical region mentioned above or is it necessary to focus on each national space separately and try to settle issues from a local-regional perspective by the international community together with the internal forces directly involved in conflict?

-is there today a unified European view on multiculturalism applicable at national level? This is, in fact, the issue over which the analysis focuses.
\end{abstract}

\section{Keywords: multiculturalism, failure, migration, European Union}

\section{Introduction}

From a political perspective, multiculturalism refers to the presence on a state's territory of more than one community, be it ethnic or religious. It is about national minorities (which should be identified as „old multiculturalism”), communities resulting from immigration, those seeking temporary work and even persons seeking asylum (these three aspects, strongly favoured by globalization, can be grouped under the ,new multiculturalism”). From this perspective one might say that this is a common feature of the world's states. Thus, from the multitude of examples, only at the European Union's level, there can be mentioned:

- Romania - according to data provided by the National Institute of Statistics, after the census of 2011, about $17 \%$ of the population was declared of other ethnicity than Romanian [1];

- The United Kingdom - in the census of 2011 , only $60 \%$ of the population said their religion was Christian [2];

- France - according to estimates 
from 2015 , about $65 \%$ of the population is Christian [3];

- Germany - the 2011 census revealed that approximately $12 \%$ of the total population has immigration origins [4].

But multiculturalism is not a strictly specific aspect of today's time. The ubiquity of multiculturalism in different national spaces has a historical explanation. Thus, in Romania [5]: German colonization process was spread over several centuries (mid- $12^{\text {th }}$ century - the late eighteenth century); Bulgarian diaspora was formed through emigration from Bulgarian lands north of the Danube, during the Ottoman rule; Jewish presence in Romania is certain since the centuries of the Middle Ages; in what the Hungarians are concerned, they were settled in the intra-Carpathian area in the $12^{\text {th }}-13^{\text {th }}$ centuries etc.

Multiculturalism is, from this perspective, a product of the "clash" of populations (some of them under territorial expansion, aiming for economic or military purposes), and also of the various forms of state organization (some of them more powerful, holding the necessary tools to design interests on foreign territories). Regarding Great Britain and France, the existing multiculturalism in these national spaces seems to be a logical consequence of their years of colonial rule, but today coexistence of the representatives of the colonial power and the colonial subjects is done in the metropolis. For Germany, multiculturalism can be explained by economic attractiveness that this state has instilled to immigrants and not just to the European ones.

\section{European Approach of the Multiculturalism Issue}

The issue of multiculturalism in the European Union must be addressed on two levels. We can thus speak about multiculturalism on which is in fact built the Union and which is generically translated by "diversity" - a community of nations that have agreed to operate under a single umbrella, "unity in diversity." But in addition to this first aspect, which refers to relations between Member States, thus "European multiculturalism", the "national multiculturalism" issue is also included, which is very different from state to state, both as particular or historical situation of the phenomenon, as well as political approach and legislative regulation.

"Old multiculturalism" is a result of a historical process, developed over a longer period of time (several hundred years), and is the product of voluntary or imposed coexistence between people of different cultures, people who today have the citizenship of the state that exercises authority and sovereignty on a territory clearly delimitated and defined in legal terms. This type of multiculturalism rather has a „national” character.

Regarding minorities, in the European Union there are important regulations concerning national minorities, their rights and the obligation of countries whose nationals they have to protect. Moreover, respect for minority rights is defined as one of the values that lies at the foundation of European integration and is explicit (re)affirmed in Article 2 of the Treaty on European Union: „The Union is founded on the values of respect for human dignity, freedom, democracy, equality, the rule of law and respect for human rights, including the rights of persons belonging to minorities. These values are common to the Member States in a society in which pluralism, non-discrimination, tolerance, justice, solidarity and equality between women and men prevail" [6]. When it comes to minorities' rights, as criteria taken into consideration during the accession process, power on how regulatory issues related to the topic are addressed remains the Member States' task, according to their constitutional order.

„New multiculturalism" is, instead, a relatively recent process, initiated after the Second World War (especially after completing the process of decolonization 
worldwide) and accelerated since the last decade of the last century when, due to the process of democratization, globally freedoms and human rights have taken a new dimension. But this kind of multiculturalism has rather a "European" character (the analytical area of interest being the European Union) of at least three reasons:

-Many of the developed countries have become the target destination for refugees and immigrants;

- These states were largely colonial powers;

- And also these states, in the fight for power, have embraced and then disavowed multiculturalism, declaring bankruptcy of the integration process in their own societies to those in search of a safer place in terms of political and/or economic matters.

People's freedom of movement creates obvious opportunities and challenges. If under the first aspect, it is about the individual (who he can find fertile ground for development and improvement of his or her living standards) and the economy of the state of destination (if we are facing an aging population and its implications for the labour market), in terms of second aspect, we can talk of society (possible conflicts that may follow as a result of the inability of immigrants to integrate and of the community to accept them, especially in times of economic turbulence) and the state of destination itself (illegal immigration becoming a matter of national security). Which means that the movement of people, generating rights and obligations for those covered by them, must be interpreted according to the nature of migration, i.e. legal or illegal, but also to making a clear distinction between "immigrant" and "refugee".

\section{The European Failure of the "New Multiculturalism"}

The EU migration policy is not sufficiently developed, given the waves of migration from the Middle East and North Africa which we must cope with. In an effort to address this issue, "A European agenda on migration" [7] was thus developed in which, reiterating the importance of the European Union as " $a$ safe haven for those fleeing persecution as well as an attractive destination for the talent and entrepreneurship of students, researchers and workers", the need for a common vision on the issue of migration was clearly underlined for the purposes of developing " $a$ set of core measures and a consistent and clear common policy". Therefore, it is officially recognized, both the lack of specific regulations so as to ensure timely and effective intervention regarding this issue, but the distinction between immigrant and refugee is also made. Development of such a policy will probably be a difficult step given the complexity of the phenomenon that normally generates an approach on multiple levels, as well as the multitude of actors called upon to get involved: "This requires using all the policies and tools at our disposal - combining internal and external policies to best effect. All actors: Member States, EU Institutions, International Organisations, civil society, local authorities and third countries need to work together to make a common European migration policy a reality."

In addition to these issues related to possible difficulties, an idea already mentioned must thus be reaffirmed - namely the repositioning of some European governments, with a very strong voice within the organization, related to the issue of multiculturalism which, as already shown, is a product to which immigrants and refugees contribute. If a few decades ago, multiculturalism generated by the immigration's phenomenon was seen as a way of solving existing problems in Western countries, primarily the labour shortages, in recent years it has begun to be perceived as a means of enhancing them or as a source of new problems. 
"Multiculturalism has failed" said all the leaders of European powers:

- According to the German Chancellor Angela Merkel's statement in 2010, the project of building a multicultural society in Germany has ,utterly failed" [8]. It was rather a political statement intended to calm the state of mind in the country at that time, fuelled by the economic crisis, according to which immigrants were not only looking for social benefits that Berlin was offering. The declaration was made about a year after her party had won the elections of September 2009, a victory which was, however, not easy. Therefore, if at the 2005 elections, the Christian Democratic Union won $35.3 \%$ of votes, followed by the Social Democratic Party with $34.2 \%$, in the 2009 elections, the Christian Democratic Union won 33.8\% of votes, but only by making alliance with the Christian Social Union. Moreover, to enter the government, the coalition with the Liberal Party had to be made [9]. On the other hand, the economy contracted by $5 \%$ in 2009, being considered the most unfavourable year after the Second World War economically speaking [10]. The wave of immigrants that Europe has been facing since the fall of 2015 highlights the role and place of immigrants/refugees into German society. The approach is also considered from an economic perspective, except that today we are not only interested in the labour force, but in human resources;

- In turn, Nicolas Sarkozy, as president of France (2011), admitted that multiculturalism not only proved to be a failure, but at the shelter of this concept, Islamic extremism has in fact blossomed. In 2015, history would reconfirm with blood that France had actually failed to create a „,national community” [11];

- During his first speech as a prime minister on problems concerning radicalisation and causes of terrorism (2011), David Cameron firmly condemned the failure of the doctrine concerning the state of multiculturalism which, instead of solving the problem of better integrating the foreigners in the British society, it smoothed the path to segregation and failed to supply a ,vision of society" desirable to all people. In this context, he underlined the necessity that his country needed a stronger national identity to prevent people turning to all kinds of extremism. Moreover, he warned those groups promoting Islamist extremism [12]. But it seems that David Cameron was not the only British prime minister to talk against extremism and to act against it. In this respect, we should mention Tony Blair, after the $7^{\text {th }}$ of July 2005 London bombings. In connection with the British case, one more thing should be mentioned: local elections in May 2016 that brought to the forefront of the London metropolis a Muslim citizen of Pakistani origin. Could Britain be so exceptional in regard to multiculturalism or has it been a victory that can only be explained by ideological issues - a Labour Party member was preferred instead of a Conservative one, thus putting an end after eight years, to the local right-wing political governance.

\section{Possible Causes of the "New Multiculturalism" Failure}

The issue of the present migration wave is not simple at all given the political and economic context at the European level but not only. From the economic perspective, the European Union is not back on the track and the perspective are not very bright considering those opinions announcing a new global financial crisis. From the political point of view, extremist rightist forces seem to find a quite comfortable place in the European citizens' preferences. The terrorist attacks in France (2015) and Belgium (2016) not only that have raised serious questions about the ability of states to defend their citizens at home, but also determined some (radical) voices to characterized these states as "failed" in this regard. In an attempt to cope with the wave of migrants/refugees, Europe closes itself internally by building border fences.

It is a situation like ,states are 
coming home." It is a time of multiculturalism denial and nationalism (re)assertion. But the causes of the multiculturalism failure (especially in the Western countries) are not to be found in the time elapsed since the onset of migratory wave.

The roots are much deeper and every investigation and solution should highlight the migration policy itself - how the phenomenon was seen by each government through the cost-benefit balance.

Long before the previously mentioned leaders stated the failure of this policy, former Spanish Prime Minister Jose Maria Aznar said in 2006, a year after the riots ethnic minority in France, that failure can be explained by the special laws that have been developed in order to integrate the migrants into the destination societies. In this respect it can be said that such a legislation has led to a social category with double rights - on one hand, those specific for the states 'residents, and on the other hand, those specific for immigrants and meant to integrate them. And such different laws eventually led to the division of the society. "To accept different laws, depending on the origin ethnic or the religion is a very serious mistake in our society [...] in a free society" [13].

The failure of multiculturalism in Europe can be explained using arguments such as:

- The European Union supranational architecture pictures the organization as being authoritarian, fact that generates adverse reactions from the Member States;

- The European Union's inability to recover and, as a natural consequence, the serious economic frustration of European citizens;

- The national governments „chase” after cheap labor amid falling birth rates in their own countries;

- The crisis of the European societies unable to develop a common set of values;

- The exaggerate importance given to the foreigners' values and habits which has alleviated gradually the links between them (minority) and the nationals (majority).

\section{Conclusions}

The existence of ethnic and religious minorities cannot be denied, at least in the European Union democratic states. In this respect one might say that multiculturalism (another word for diversity) has become a main feature of the European Union and it must be managed to meet the needs of social harmonization and spiritual enrichment, and not to be used as an instrument of division within society or as an argument used in a circumstantial manner inside the political struggle.

Unfortunately, also in this case, reality has raced ahead of theory. Inconsistent legislation both at the European and national level, policies devoid of vision and pragmatism, confusion of terms (,immigrant” and „refugee”) by purpose or not are today some of the sources of the situation encountered in the European Union as a result of the migration flows from the Middle East and North Africa.

\section{References}

[1] http://www.recensamantromania.ro/rezultate-2/.

[2] https://www.ons.gov.uk/peoplepopulationandcommunity/culturalidentity/ ethnicity/adhocs/005528ct05752011 censusethnicgroupwriteinresponsebyreligionengland.

[3] https://www.cia.gov/library/publications/the-world-factbook/geos/fr.html.

[4] https://www.zensus2011.de/DE/Home/home node.html.

[5] http://hiphi.ubbcluj.ro/Public/File/sup curs/istorie16.pdf (Istoria şi tradiţiile minorităţilor din România, Toader Nicoară).

[6] http://eur-lex.europa.eu/LexUriServ/LexUriServ.do?uri=OJ:C:2008:115:0013:0045:en:PDF 
[7] http://ec.europa.eu/dgs/home-affairs/what-we-do/policies/european-agendamigration/background-

information/docs/communication_on_the_european_agenda_on_migration_en.pdf.

[8] http://www.bbc.com/news/world-europe-11559451.

[9] http://www.agerpres.ro/flux-documentare/.

[10] https://www.theguardian.com/business/2010/jan/13/globalrecession-germany.

[11] http://www.cbn.com/cbnnews/world/2011/february/frances-sarkozy-multiculturalismhas-failed/?mobile=false.

[12] http://www.bbc.com/news/uk-politics-12371994.

[13] http://www.freerepublic.com/focus/f-news/1726950/posts. 